\title{
Klinik Hemşirelerinin Öğrenci Hemşirelerin Eğitimine Katılımındaki Engellerin Belirlenmesi
}

\section{Identifying Hinders of Clinical Nurses to Participation in the Training of Nursing Students}

\author{
Seda Şahan ${ }^{1}$ (iD) Şefika Dilek Güven ${ }^{2}$ \\ ${ }^{1}$ İzmir Bakırçay Üniversitesi, Sağlık Bilimleri Fakültesi, Hemşirelik Bölümü, Hemşirelik Esasları Anabilim Dalı, İzmir, TÜRKIYE \\ ${ }^{2}$ Nevşehir Hacı Bektaş Veli Üniversitesi, Semra ve Vefa Küçük Sağlık Bilimleri Fakültesi, Hemşirelik Bölümü, Hemşirelik Esasları Anabilim Dalı, \\ Nevsehir, TÜRKIYE
}

Gelis tarihi/ Date of receipt: 01/09/2020 Kabul tarihi/ Date of acceptance: 25/11/2020

(c) Ordu University Faculty of Health Sciences, Department of Nursing, Turkey, Published online: 31/12/2020

\section{ÖZ}

Amaç: Hemşirelik eğitimi, sınıfta, beceri laboratuvarında ve klinik ortamda gerçekleştirilen bir süreçtir. Klinik uygulama hemşirelik eğitiminin en az yarısını kapsar ve sınıfta öğretilen teorik bilgilerin uygulamaya, hasta bakımına geçirilmesine olanak sağlar. Sağlik bakım ortamlarında klinik uygulama hemşirelik eğitiminin temelidir. Klinik hemşirelerinin, öğrencilerin eğitimine katılımdaki engellerinin belirlenmesi ve bu engellere çözüm üretilmesi hemşirelik eğitim sürecinin etkinliği bakımından oldukça önemlidir. Bu araştırmada, bir devlet hastanesinde çalışan hemşirelerin öğrenci hemşirelerin eğitimine katılımına engel olan durumların belirlenmesi amaçlanmiştır.

Yöntem: Araştırma klinik hemşirelerinin, öğrenci hemşirelerinin eğitimine katılımlarındaki engellerin belirlenmesi amacıyla tanımlayıcı tipte yapılmıștır. Araştırmanın örneklemini Nevşehir Devlet Hastanesi’nde çalışan 150 hemşire oluşturmuştur. Veriler hemşirelerin tanıtıcı özellikleri ve öğrenci hemşirelerinin eğitimine katılımlarındaki engellerin belirlenmesi amacıyla hazırlanan anket formu ile toplanmıştır. Veriler SPSS 22.0 programında sayı ve yüzde olarak değerlendirilmiştir.

Bulgular: Araştırma sonucuna göre, hemşirelerin \%46.7'si öğrencinin klinikte öğrenmesi gereken konu ve becerileri klinik hemșiresinden öğrenmek için kendisinin çabalamamasını, \%60.7'si öğrenci sayısının fazla olmasını, \%42.2'si bazı öğretim elemanlarının klinikte yeterince bulunmamasını, \%36.0'sı hastane fiziki ortamının yetersiz olmasını öğrenci eğitimine katılmada engel olarak ifade etmiștir.

Sonuç: Hemşirelerin öğrenci hemşirelerin eğitimine katılımında hemşirelerden kaynaklanan engellerin daha az, öğrencilerden kaynaklanan engellerin ise daha fazla olduğu belirlenmiştir.

Anahtar Kelimeler: Hemşirelik, hemşirelik eğitimi, klinik uygulama, klinik eğitimde engeller

\footnotetext{
ABSTRACT

Objective: Nursing education is a process carried out in class, skills lab and clinical environment. Clinical practice covers at least half of the nursing education and allows the theoretical knowledge taught in the class to be put into practice and patient care. Clinical practice in health care environment is the basis of nursing education. Determining the obstacles of clinical nurses in participating in the education of students and finding solutions to these obstacles are very important in terms of the effectiveness of the nursing education process. In this research, it was aimed to determine the hinders for the participation of nurses working in a state hospital to the education of student nurses.

Methods: The research was carried out in a descriptive manner to determine the hinders to participation of clinical nurses in the training of nursing students. The sample of the study consisted of 150 nurses working at a State Hospital. The data were collected by a survey form designed to identify the nurse's descriptive characteristics and the hinders to participation in the training of the nursing students. The data were evaluated in SPSS 22.0 program with numbers and percentage values.

Results: According to the results of the study, $46.7 \%$ of the nurses stated as a hinder to participation to training of nursing students that the students did not make effort to learn the subjects and skills that should be learned in the clinic from the clinical nurse, $60.7 \%$ of the nurses stated the higher number of students as a hinder to participation to training of nursing students , $42.2 \%$ of the nurses stated absence of some instructors in the clinic as a hinder to participation to training of nursing students and $36.0 \%$ of the nurses stated that the inadequate physical environment of the hospital was an hinder to participation in student training.

Conclusion: It was determined that the nurse-originated hinders were less than student-originated hinders in nurses' participation in the training of the nursing students.

Keywords: Nursing, nursing education, clinical practice, hinders in clinical education

ORCID IDs of the authors: SS: 0000-0003-4071-2742, SDG: 0000-0002-2761-4665

Sorumlu yazar/Corresponding author: Arş. Gör. Seda Şahan

İzmir Bakırçay Üniversitesi, Sağlık Bilimleri Fakültesi, Hemșirelik Bölümü, Hemșirelik Esasları Anabilim Dalı, İzmir, TÜRKIYYE

e-posta/e-mail: seda.sahan@bakircay.edu.tr

Atıf/Citation: Şahan S, Güven ŞD. (2020). Klinik hemşirelerinin öğrenci hemşirelerin eğitimine katılımındaki engellerin belirlenmesi. Ordu Üniversitesi Hemșirelik Çalıșmaları Dergisi, 3(3), 218-225. DOI: 10.38108/ouhcd.765953
} 


\section{Giriş}

Hemşirelik eğitimi, sınıfta, beceri laboratuvarında ve klinik ortamda gerçekleștirilen bir süreçtir. Klinik uygulama hemşirelik eğitiminin en az yarısını kapsar ve sınıfta öğretilen teorik bilgilerin uygulamaya ve hasta bakımına aktarılmasına olanak sağlar (Elcigil ve Sarı, 2007; Günay ve Kılınç, 2018). Klinik öğretim, hemşirelik eğitim sürecinin önemli bir kısmını oluşturmaktadır. Klinik öğretimin temel amacı hemşirelik öğrencilerinin mesleki bilgi ve becerilerini geliştirmektir, aynı zamanda araştırma, eleştirel düşünme, bağımsız karar verme, etkili kişilerarası iletişim ve hemşirelik mesleğini yerine getirmede kendine güven gibi becerilerin gelişmesini de sağlamaktadır (Elcigil ve Sarı, 2007).

Klinik öğretim, öğrenim hedefleri doğrultusunda seçilen kliniklerde gerçekleştirilmektedir (Karaöz 2003). Klinik eğitimin öğrenciler için uygun bir öğrenme çevresi olmasında klinik hemşireler ve sağlık ekibi üyelerine, öğretim elemanlarına, okul ve hastane yöneticilerine önemli görev ve roller düşmektedir (Kaya ve ark., 2000; Karaöz 2003; Aytekin ve ark., 2009). Klinik öğretim yalnızca öğretim elemanı ve öğrenci arasında yürütülen bir süreç olmamaktadır (Akyüz ve ark., 2007). Klinik öğretimin süresince öğretim elemanları ve hemşirelerin iş birliği içinde çalışması öğrencilere rol model olmakta ve eğitimi etkin kilmaktadır (Konak ve ark., 2008). Öğrenci hemşireler, sağlık ekip üyelerinden destek ve kabul gördüklerinde kendilerini mesleğe ait hissetmekte ve öğretimde başarıları artmaktadır (Eskimez ve ark., 2005). Klinik öğretimin başarısı, öğrenci eğitimine destek olan klinik hemşirelerine bağlıdır (Konak ve ark., 2008).

Ülkemizde klinik hemşirelerinin eğitime desteğini inceleyen çalışmalarda öğrenciler çoğunlukla destek almadıklarını belirtmiş̧tir ( Elcigil ve Sar1, 2007; Rahmani ve ark., 2011; Akgün ve ark., 2012; Biçer ve ark., 2015). Hemşirelik eğitiminin kalitesini artırmak, mesleki profesyonelliği sağlamak, bakım hizmetlerinin kalitesini artırmak için hemşirelik okullarının ve hastane yöneticilerinin iş birliği içinde çalışması önemlidir (Konak ve ark., 2008). Literatürde hemşirelik öğrencilerinin rol model olan, mesleki donanım ve beceriye sahip hemşirelerle çalışmalarının gelişimlerini olumlu etkilediği (Akyüz ve ark., 2007; Akgün ve ark., 2012), hemşirelik öğrencilerinin, iş birliği içinde çalışabildikleri, iletişim problemleri yaşamadıkları klinik öğretim ortamlarından daha çok faydalandıkları belirtilmektedir (Elcigil ve Sar1, 2007; Akgün ve ark., 2012).

Türkiye'de klinik hemşirelerinin öğrenci eğitimi konusunda yasal sorumluluğa da vardır. Resmi Gazete'de 8 Mart 2010 tarihinde yayınlanan 27515 No'lu Hemșirelik Yönetmeliği'nde "Hemșirelikle ilgili eğitim, danışmanlık, araştırma faaliyetlerini yürütür. Toplumun, öğrenci hemşirelerin, sağl1k çalışanlarının ve adaylarının eğitimine destek verir ve katkıda bulunur", "Öğrenci hemşirelerin eğitimi için uygun çalışma ortamını oluşturur, öğretim elemanları ile iş birliği yaparak okul-hastane iş birliği sağlar", "Öğrenci hemşirelerin eğitiminde uygun eğitim ortamı sağlar" ifadeleri yer almaktadır (Hemşirelik Yönetmeliği 2010).

Literatür incelendiğinde öğrenci hemşirelerin, klinik hemşireleri hakkında, klinik hemşirelerinin ise iş birliği hakkındaki görüssleri ile ilgili farklı çalışmalar yapılmıştır fakat klinik hemşirelerinin, öğrenci hemşirelerinin eğitimine katılmalarındaki engellerini belirleyen bir çalışma rastlanmamıştır. Klinik hemşirelerinin öğrenci hemşirelerin eğitimine katılımına ve öğrencilerin öğrenmelerine engel olan durumlarin belirlenmesi, engel olan durumlara çözüm üretilmesi ve bu vasitayla öğrenmelerine olumlu katkı sağlanması hemşirelik eğitiminin kalitesini arttıracağından önemlidir. $\mathrm{Bu}$ nedenle çalışmamızda, klinik hemşirelerinin öğrenci hemşirelerin eğitimine katılımındaki engellerin belirlenmesi amaçlanmıştır.

\section{Yöntem}

Tanımlayıcı olarak yürütülen bu çalışmanın evrenini Nevşehir Devlet Hastanesi'nde çalışan 230 hemşire oluşturmuştur. Ön uygulama yapılan 10 hemşire, çalışmanın yapıldığı tarihler arasında izinde olan 20 hemşire, araştırmaya katılmak istemeyen 50 hemşire örneklem dişında bırakılmıştır ve araştırma 150 hemşire ile tamamlanmıştır.

Veriler literatür taranarak oluşturulan anket formu ile toplanmıştır (Akgün ve ark., 2012; Akyüz ve ark., 2007; Atay ve ark., 2009; Bayar ve ark., 2009; Birol 2009; Erenel ve ark., 2008; Erken 2008; Eskimez ve ark., 2005; Häggman-Laitila ve ark., 2007; Keser ve ark., 2008; Kocaman 2004; Taylan ve ark., 2012). Anket formu hemşirelerin tanitıcı özellikleri ile ilgili 12 soru, hemşirelerden kaynaklanan engellerin belirlenmesi için 25 soru, öğrencilerden kaynaklanan engellerin belirlenmesi için 12 soru, öğretim elemanlarından kaynaklanan 
engellerin belirlenmesi için 13 soru, klinik/hastaneden kaynaklanan engellerin belirlenmesi için 6 soru, hemşirelerin hemşirelik öğrencilerinin eğitimine verecekleri katkının nasıl olması gerektiğine ilişkin görüşlerinin belirlenmesine yönelik 1 soru olmak üzere toplamda 69 sorudan oluşmuştur. Araştırma verileri hemşirelerin daha az izne ayrılma tarihleri olan 1 Ekim- 31 Aralık 2018 yüz yüze görüşme yöntemi ile toplanmıştır. Bir kişi ile görüşme yaklaşık 10 dakika sürmüştür. Çalışmadan elde edilen verilerin değerlendirilmesi amaciyla SPSS (Statistical Package for Social Sciences) 22.0 version kullanılarak sayı ve yüzde olarak değerlendirilmiştir.

\section{Bulgular}

Hemşirelerin \%45.3'ünün (n:68) 30-39 yaş grubunda, \%85.3'ünün (n:128) kadın, \%44.0'nün (n:66) lisans mezunu, \%80.7'sinin (n:121) haftada
40 saat çalıştığ 1 belirlenmiştir. Hemşirelerin \%48.7'si (n:73) “öğrencinin klinik hemşiresinden öğrenmek için kendisinin çaba göstermemesi"ni hemşirelerden kaynaklanan (Tablo 1), \%60.7'si (n:91) "öğrenci sayısının fazla olması" "nı öğrenciden kaynaklanan (Tablo 2), \%42.0'si (n:63) “baz1 öğretim elemanlarının klinikte yeterince bulunmaması"nı öğretim elemanından kaynaklanan (Tablo 3), \%36.0's1 (n:54) "hastane fiziki ortamının yetersiz olması"nı klinik/hastaneden kaynaklanan engel olarak ilk sırada ifade etmiştir (Tablo 4).

Hemşirelerin öğrenci eğitimine verecekleri katkıyı; hemşirelerin \%50.0'si (n:75) işlem sirasinda ögrrenciye uygulamayl gösterme, \%29.3'ü $(\mathrm{n}: 44)$ eğitim ve hemşirelik hizmetlerinin okul ve hastane ile ortaklaşa planlanması, \%24.7'si (n:37) dersin değerlendirmesini hemşireler ve ögretim elemanlarının birlikte yapması olarak belirtmiştir (Tablo 5).

Tablo 1. Klinikte Çalışan Hemşirelerin Öğrenci Hemşirelerin Eğitimine Katılımlarındaki Hemşirelerden Kaynaklanan Engeller

\begin{tabular}{lcc}
\hline Hemşirelerden Kaynaklanan Engeller & n & $\%$ \\
\hline Öğrencinin klinik hemşiresinden öğrenmek için kendisinin çaba göstermemesi & 73 & 48.7 \\
\hline Öğrencilerin iş yoğunluğunu arttırması & 69 & 46.0 \\
\hline Hemşire sayısının yetersiz olması & 66 & 44.0 \\
\hline Öğrenci eğitimine katılmak istememe & 24 & 16.0 \\
\hline Öğrencilerle iş birliği sonucu maddi karşılık almama & 24 & 16.0 \\
\hline Hemşireliği iş merkezli olarak düşünme & 23 & 15.3 \\
\hline Öğrencinin varlığının, hastaya ayırdığım zamanı kısıtlaması & 23 & 15.3 \\
\hline Öğrenci hemşirelerle kendini meslektaş olarak görmeme & 22 & 14.7 \\
\hline Öğretimi ikinci planda görme & 21 \\
\hline Öğrencilerden sadece öğretim elemanlarının sorumlu olduğunu düşünme & 21 \\
\hline Öğrencilerle iş birliğini görevi olmadı̆̆ını düşünme & 20 \\
\hline
\end{tabular}

Tablo 2. Klinikte Çalışan Hemşirelerin Öğrenci Hemşirelerin Eğitimine Katılımlarındaki Öğrencilerden Kaynaklanan Engeller

\begin{tabular}{lcc}
\hline Öğrencilerden Kaynaklanan Engeller & $\mathbf{n}$ & $\boldsymbol{\%}$ \\
\hline Öğrenci sayısının fazla olması & 91 & 60.7 \\
\hline Öğrencilerin hemşirelerle etkili iletişim kuramıyor olması & 62 & 41.3 \\
\hline Öğrencilerin hasta bakım uygulamalarını yanlış yapıyor olması & 59 & 39.3 \\
\hline Öğrencilerin teorik bilgilerini klinikte kullanamıyor olması & 52 & 34.7 \\
\hline Öğrencilerin sadece öğretim elemanlarını rol model olarak alıyor olması & 45 & 30.0 \\
\hline Öğrencilerin hemşirelik bakımı ile ilgili sorunlarda yardım istemiyor olması & 41 & 27.3 \\
\hline Öğrencilerin tıbbı malzemeye zarar verebilecekleri endişesi yaşama & 31 \\
\hline Öğrencilerle uyumlu çalışamıor olma & 27 & 20.7 \\
\hline Öğrencilerin uygulamada eksikliklerinin olması & 11 & 7.3 \\
\hline Öğrencilerin öğrenmeye istekli olmaması & 9 & 6.0 \\
\hline
\end{tabular}


Tablo 3. Klinikte Çalışan Hemşirelerin Öğrenci Hemşirelerin Eğitimine Katılımlarındaki Öğretim Elemanlarından Kaynaklanan Engeller

\begin{tabular}{lcc}
\hline Öğretim Elemanlarından Kaynaklanan Engeller & n & \% \\
\hline Bazı öğretim elemanlarının klinikte yeterince bulunmaması & 63 & 42.0 \\
\hline Bazı öğretim elemanlarıyla hemşireler arasında uygulama farklılıklarının olması & 45 & 30.0 \\
\hline Bazı öğretim elemanlarının iş birliği yapmaması & 45 & 30.0 \\
\hline Bazı öğretim elemanlarından kaynaklanan iletişim sorunlarının yaşanması & 42 & 28.0 \\
\hline Bazı öğretim elemanlarıyla kendisini meslektaş olarak görmeme & 34 & 22.7 \\
\hline Bazı öğretim elemanlarının araştırmalarına hemşireleri dahil etmemesi & 24 \\
\hline Bazı öğretim elemanlarıla hemşirelik mesleğinin sorumluluklarıyla ilgili & 21 \\
fikir ayrılıklarının olması & 14.0 \\
\hline Öğrencilerin klinik uygulama değerlendirilmelerine hemşirelerin dahil edilmemesi & 20 \\
\hline Bazı öğretim elemanlarının klinik uygulamaları öğrenciyle birlikte yapmıyor olması & 5 & 13.3 \\
\hline Bazı öğretim elemanlarının klinikte yeterince bulunmaması & 63 \\
\hline
\end{tabular}

Tablo 4. Klinikte Çalışan Hemşirelerin Öğrenci Hemşirelerin Eğitimine Katılımlarındaki Klinik/Hastaneden Kaynaklanan Engeller

\begin{tabular}{lcc}
\hline Klinik/ Hastaneden Kaynaklanan Engeller & $\mathbf{n}$ & $\%$ \\
\hline Hastane fiziki ortamının yetersiz olası & 54 & 36.0 \\
\hline Öğrencilerle klinik ortamda tartışmaların yapılacağı yerin olmaması & 40 & 26.7 \\
\hline $\begin{array}{l}\text { Yetkili yöneticiler tarafından öğrenci eğitimi konusunda yeterli bilgilendirme ve eğitim } \\
\text { yapılmaması }\end{array}$ & 40 & 26.7 \\
\hline Öğrenci eğitimine katkı veren araç gereçlerin yeterli olmaması & 34 & 22.7 \\
\hline Klinikte hasta bakımı malzemelerinin eksik olması & 27 & 18.0 \\
\hline
\end{tabular}

Tablo 5. Hemşirelerin Öğrenci Eğitimine Verecekleri Katkının Nasıl Olması Gerektiğine İlişkin Görüşleri

\begin{tabular}{lcc}
\hline Görüşler & $\mathbf{n}$ & $\mathbf{\%}$ \\
\hline İşlem sırasında uygulamayı öğrenciye gösterme & 75 & 50.0 \\
\hline Eğitim ve hemşirelik hizmetlerinin okul ve hastane ile ortaklaşa planlanması & 44 & 29.3 \\
\hline Dersin değerlendirmesini hemşireler ve öğretim elemanlarının birlikte yapması & 37 & 24.7 \\
\hline $\begin{array}{l}\text { Öğretim elemanı ve hemşirelerin hizmet içi eğitim programlarını } \\
\text { birlikte planlayıp yürütmesi }\end{array}$ & 35 \\
\hline $\begin{array}{l}\text { Hemşireler, öğrenciler ve öğretim elemanları karşılıklı toplantılarla } \\
\text { beklentilerini paylaşıp iletişimi güçlendirmeleri }\end{array}$ & 33.3 \\
\hline Klinik hemşirelerinin öğrencilerin teorik ve sınıf içi uygulamalarını takip etmesi & 22.0 \\
\hline Öğrencilerin pratik uygulamalarının artırılması & 15 \\
\hline
\end{tabular}

\section{Tartışma}

Hemşirelik eğitimi birbirini tamamlayan teorik ve klinik öğretim süreçlerinden oluşmaktadır. Klinik öğretim, öğrencilerin teorik derslerde öğrendikleri bilgileri klinik uygulamaya aktarma ve hemşirelik becerilerini yaparak öğrenme imkanı vermektedir. Klinik öğretim, teorik eğitim ile birlikte hemşirelik eğitim sürecinin önemli bir kısmını oluşturmaktadır. Klinik öğretimde öğrenciler yalnızca öğretim elemanları ile çalışmamakta klinik hemşirelerin rehberliğine ihtiyaç duymaktadırlar (Biçer ve ark., 2015). Öğrenciler, klinik öğretimde bakım hizmetlerinde rehberlik ve desteğe ihtiyaç duymaktadır. Uygulama alanlarında bu destek ve rehberlik hem öğretim elemanları hem de klinik hemşireler tarafından sağlanmalıdır (Koç ve Batkın, 2016).

Klinik uygulama ortamları, öğrencilere rol model hemşireleri gözlemleme ve birlikte çalışma imkanı sağlaması açısından da oldukça önemlidir (Akgün ve ark., 2012). Akyüz ve ark. (2007) yaptığı çalışmada hemşirelerin \%12.7'sinin öğrencilerin hemşireler bir şey öğretmese de hemşireyi izleyerek uygulamaları öğrenebileceklerini düşündüklerini, hemşirelerin \%89.1'i ise öğrencilerin klinik uygulamalarda öğrenme sorumluluğunu almalarının ve bu konuda çaba göstermelerinin gerekli olduğunu ifade ettikleri belirlenmiştir (Akyüz ve ark., 2007). Çalışmamız sonucunda hemşirelerin \%48.7'si (n:73) "öğrencinin klinik hemşiresinden öğrenmek 
için kendisinin çaba göstermemesi”ni hemşirelerden kaynaklanan engel olarak ilk sırada belirtmişlerdir (Tablo 1). Bu çalışmaya göre hemşirelerin öncelikle öğrencilerden beklentilerinin olduğunu söyleyebiliriz.

Klinik öğretim yalnızca öğrenci ve öğretim elemanın birlikte yürttüğü bir süreç olmayıp, aynı zamanda öğrencilerin klinik hemşireleri ile birlikte çalışma imkanın olduğu, hemşireler ile kaliteli bağların kurulmasını gerektiren bir eğitim sürecidir (Akyüz ve ark., 2007). Klinik hemşireleri, hemşirelik öğrencilerinin teorik bilgi ile pratik uygulamaları entegre yürütebilmesinde, profesyonel kimlik kazandırılmasında çok önemli bir role sahiptir. Öğrenci hemşirelerin klinik öğrenmesinde klinik eğiticilerinin rolü azımsanamaz (Factor ve Guzman, 2017). Klinik hemşirelerinin profesyonel hemşireliğin gereği olarak klinik ve uygulamada hemşirelik öğrencilerinin öğretimlerine yardımc1 olmaları gerekmektedir (Akyüz ve ark., 2007). Gürsoy ve ark. (2017) yaptığı çalışmada hemşirelerin \%26.9'unun 'öğrenci uygulamalarında sorumluluk almak istememeleri"'iş birliğini engelleyici faktör olarak belirlenmiştir. Çalışmamızda ise hemşirelerin \%16.0's1 (n:24) “öğrenci eğitimine katılmak istemiyorum"u hemşirelerden kaynaklanan engellerden biri olarak belirtmişlerdir (Tablo 1). $\mathrm{Bu}$ sonuç hemşirelerin öğrenci eğitimine katılmak istememelerinin okul-klinik işbirliğini, öğrencilerin klinik uygulamaya adaptasyonlarını ve klinik eğitim sürecini olumsuz etkileyebileceğini düşündürmektedir.

Klinik uygulama öğretimi, öğrencin öğrendiklerini uygulamaya aktarma, mesleki beceri ve kimlik kazanma, yaparak öğrenmesini sağlayan hemşirelik eğitim süreci olarak tanımlanabilir (Akyüz ve ark., 2007). Klinik uygulamalar, öğrencilerin klinik karar verme ve problem çözme becerisi kazanmasını, hastalara eleştirel düşünce ile yaklaşarak bilgi ve becerilerini geliştirmesini sağlamaktadır (Eskimez ve ark., 2005). Klinik ortamlar uygulama eğitiminde öğrenci ve hemşire sayısı arasında uygun olmayan oran gibi çeşitli k1sitlamalara sahiptir. Cho ve Kwon'un (2007) çalışmasında öğretim görevlisi başına 8 öğrenci, hemşire başına 20 öğrenci düştüğü belirlenmiştir (Cho ve Kwon, 2007). Addis ve Karadag'ın (2003) çalışmasında bir öğretim görevlisine 15-18 öğrenci düştüğü belirlenmiştir. Öğrenci sayısının fazla olmasının öğrenci denetlemesini zorlaştırdığ 1 , öğrencinin yaptığı klinik uygulamaları ve öğrenme firsatını azalttı $\breve{g} 1$ ifade edilmiştir (Addis ve Karadağ,
2003). Çalışmamızda hemşirelerin \%60.7'si (n:91) “öğrenci sayısının fazla olması"nı öğrenciden kaynaklanan engel olarak ilk sırada belirtmişlerdir (Tablo 2). Çalıșma sonucuna göre öğrenci sayısının fazla olmasının klinik hemşireleri ile öğrenci hemşireler arasında iletişim sorunlarına yol açabileceğini, öğrencilerin hedeflenen becerileri kazanması için hemşirelerin sorumluluklarını yerine getirmede güçlük yaşayabileceklerini düşündürmektedir.

Klinik öğretimde, teorik derslerden farklı olarak öğretim elemanı ve öğrenci arasında farklı bir eğitim süreci olduğu görülmektedir. Öğretim elemanı ve öğrenci arasında bire bir iletişim kurma firsatı sağlanarak daha yoğun bir etkileşim oluşmaktadır. $\mathrm{Bu}$ süreçte öğrenciler için öğretim elemanlarının davranış özellikleri önem kazanmakta, öğrenciler öğretim elemanlarından olumlu yada olumsuz etkilenebilmektedir (Eskimez ve ark., 2005). Gürsoy ve ark. (2017) çalıșmasında hemşirelerin \%57.8'i "öğretim elemanlarının sahadan uzak olmasını" akademik-klinik iş birliğini engelleyebilecek faktörlerden biri olarak belirtmişledir (Gürsoy ve ark., 2017). Çalışmamızda hemşirelerin \%42.0'si (n:63) "bazı öğretim elemanlarının klinikte yeterince bulunmaması"nı öğretim elemanlarından kaynaklanan engel olarak ilk sırada belirtmişlerdir (Tablo 3). Öğretim elemanlarının klinikte yeterince bulunmaması, rol model olma, öğrencilerin değerlendirilmesi, öğrenciye güven verme açısından öğrenci öğretmen etkileşiminde olumsuzluklara neden olabileceğini düşündürmektedir.

Farklı rol ve görevler üstlenerek hemşirelik mesleği için çalışan klinik hemşireleri ve akademisyen hemşirelerin öğrenci eğitimine katk1 sağlaması, sorunlara ortak çözüm yolları bulmaları, karşılıklı iletişim ve anlayış içinde iş birliği sağlamaları mesleki gelişim açısından önemlidir (Akyüz ve ark., 2007). Gürsoy ve ark. (2017) çalışmasında hemşirelerin \%56.2'si “öğretim elemanları ve klinikteki hemşireler arasında etkili bir iletişimin olmaması" $n 1$ akademik-klinik iş birliğini engelleyebilecek faktörlerden olduğunu belirtmişledir (Gürsoy ve ark., 2017). Çalışmamızda hemșirelerin \%28.0'i (n:42) “Bazı öğretim elemanlarından kaynaklı iletişim sorunları yaşıyorum"u öğretim elemanlarından kaynaklanan engellerden biri olarak belirtmişlerdir (Tablo 3). $\mathrm{Bu}$ sonuç öğretim elemanları ve klinik hemşireleri arasında iletişim sorunu olmasının öğrencilerin klinik uygulamalarına olumsuz yansıyabileceğini ve 
uygulama farklılıklarına neden olabileceğini düşündürmektedir.

Klinik ortam, hasta ve sağlıklı bireylere çeşitli bakım hizmetlerinin sunulduğu, değer ve kuralları olan profesyonel bir ortamdir. $\mathrm{Bu}$ ortam, öğrencilerin linik öğretimini etkileyen sosyal, fiziksel ve psikolojik ögeler içermekte ve öğretimin başarısını etkilemektedir. Öğrencilerin bireysel ve mesleki gelişimini sağlayacak bir ortamda olması klinik öğretim için oldukça önemlidir (Biçer ve ark., 2015). Konak ve ark. (2008) çalışmasında hemşireler, öğrencilerin uygulama yaptığı hastanenin fiziksel şartları, hasta vakalarının çeşitliliği bakımından kısmen uygun ve orta düzeyde uygun olarak görmektedirler (Konak ve ark., 2008). Çalışmamızda hemşirelerin \%36.0's1 (n:54) "hastane fiziki ortamının yetersiz olması"nı klinik/hastaneden kaynaklanan engel olarak ilk sırada belirtmişlerdir (Tablo 4). Çalışmamız sonucuna göre klinik/hastaneden kaynaklanan engellerin olması ve çözülememesi okul-hastane iş birliği sürecini ve öğrenci hemşire, öğretim elemanları ve hemşireler arasındaki klinik eğitim sürecini olumsuz etkileyeceğini düşündürmektedir.

Klinik alan sağlık profesyonellerinin özelliklede hemşirelerin eğitiminde uygulamaları öğrenmek için gerekli bir alan olarak tanımlanmıştır. Klinik uygulama hemşirelik eğitiminin büyük ve önemli bir parçasıdır. Klinikteki deneyimler öğrencilerin uygulama, profesyonel gelişim ve öğrenme tutumlarını şekillendirmede etkilidir. Eğitim sürecinde öğrencinin nasıl ve ne şekilde öğrendiği önemlidir (Henderson ve ark., 2012). Öğrenciler için elverişli öğrenme çevresinin yaratılmasında, öğretim elemanları ile birlikte klinik hemşirelerine, yöneticivilere ve diğer Sağlik ekibi personellerine önemli rol ve görevler düşmektedir (Konak ve ark., 2008). Konak ve ark. (2008) çalışmasında hemşireler öğrenci eğitimine verilebilecek katkıyı, uygulamalara öğretmenler ile birlikte çıkarak, teorik ve uygulamalarına katkıda bulunarak, teorik derslere katk1 vererek yapabileceklerini ifade etmişlerdir (Konak ve ark., 2008). Gürsoy ve ark. (2017) yaptığı çalışmada ise hemşirelerin \%89.0'u öğrencilerle en çok iş birliği yapmak istedikleri konuların başında; "öğrencilerin pratik eğitimi", geldiğini ifade etmişlerdir (Gürsoy ve ark., 2017). Çalışmamızda hemşirelerin \%50.0'si (n:75) öğrenci eğitimine verecekleri katkıyı işlem sırasında öğrenciye uygulamayı gösterme olarak ifade etmişlerdir (Tablo 5). $\mathrm{Bu}$ sonuçlar klinik hemşirelerinin öğrencilerin eğitiminde sorumluluk almayı istediklerini göstermektedir. Klinik hemşirelerine öğrenci eğitiminde sorumluluk verilmesi okul-klinik iş birliğinin olumlu yönde gelişmesine katkı sağlaması açısından da önemlidir.

\section{Sonuç ve Öneriler}

Çalışma sonucuna göre, hemşirelerin öğrenci hemşirelerinin eğitimine katılımında kendilerine özgül engellerin daha az, öğrencilerden kaynaklanan engellerin ise daha fazla olduğunu belirttikleri saptanmıştır. Saptanan engellerin çözülememesi okul-hastane iş birliği sürecini ve öğrenci hemşire, öğretim elemanları ve hemşireler arasındaki klinik eğitim sürecini olumsuz etkileyeceğini düşündürmektedir. Klinik hemşirelerine öğrenci eğitimi ile ilgili ihtiyaçlarına yönelik ve kapsamlı eğitimler verilmesi önemlidir. Kliniklerdeki öğrenci-hemşire oranı, klinik kapasiteleri, vaka çeşitliliği, bakım hizmetlerinin gereksinimleri ve öğrenci sayıları göz önüne alınarak kliniğe çıkacak öğrenci sayılarının belirlenmesi, öğrenciler, öğretim elemanları ve klinik hemşirelerinin karşılıklı toplant1 yaparak birbirlerinden beklentilerini ifade etmeleri önerilebilir.

\section{Araştırmanın Etik Yönü/ Ethics Committee Approval:}

Araştırmaya başlamadan önce Nevşehir Devlet Hastanesi'nden yazılı izin (69886531-806.02.02), araştırmanın yapıldığı ildeki üniversitenin etik kurulundan etik izin (84902927) ve araștırmaya katılan hemşirelerden de bilgilendirilmiş onam formu ile yazılı izin alınmıştır. Hemşirelere çalışmanın amacı, gerekçesi, veri toplama süreci hakkında bilgi verilmiş, araştırmaya katılmalarının kendileri için bir risk getirmeyeceği, araştırmaya katılmayı kabul etmeleri halinde, kimlik bilgilerinin gizli kalacağı, istedikleri anda çalışmadan ayrılabilecekleri belirtilmiştir. $\mathrm{Bu}$ açıklamalar sonucunda, araştırmaya katılmayı kabul eden öğrencilerin bilgilendirilmiş sözlü onamları alınmıştır. Araştırmada Helsinki Deklerasyonu ilkelerine uyulmuştur. Kullanılan literatür kaynaklar bölümünde gösterilmiştir.

Hakem/Peer-review: Dış hakem değerlendirmesi.

Yazar Katkısı/Author Contributions: Fikir/kavram: SŞ, ŞDG; Tasarım: SŞ, ŞDG; Danışmanlık: ŞDG; Veri toplama: SŞ; Veri işleme:SŞ; Analiz ve/veya Yorum: SŞ, ŞDG; Kaynak tarama: SŞ, ŞDG; Makalenin Yazımı: SŞ, ŞDG; Eleştirel inceleme: ŞDG.

Çıkar çatışması/Conflict of interest: Çalışmada herhangi bir çıkar çatışması söz konusu değildir.

Finansal Destek/Financial Disclosure: Herhangi bir finansal destek alınmamıştır. 


\section{Çalışma Literatüre Ne Kattı?}

- Hemşireler, öğrenci hemşirelerinin eğitimine katılımında kendilerine özgül engellerin daha az, öğrencilerden kaynaklanan engellerin ise daha fazla olduğunu belirtmiştir.

- Hemşireler, klinik öğretimde öğrencilerin çabalaması gerektiğini düşünmektedirler.

- Engellerin belirlenmesi, iş birliğinin sağlanması, öğrenci eğitim kalitesinin artırılması yönünden önemlidir.

\section{Kaynaklar}

Addis G, Karadag A. (2003). An evaluation of nurses' clinical teaching role in Turkey. Nurse education today, 23(1), 27-33.

Akgün Kostak, Aras T, Akarsu Ö. (2012). Hemşirelik öğrencilerinin klinik hemşirelerin eğitimlerine verdiği katkıya ilişkin görüşleri. Cumhuriyet Hemşirelik Dergisi, 2, 39-46.

Akyüz A, Tosun N, Yıldız D, Kılıç A. (2007). Klinik öğretimde hemşirelerin, kendi sorumluluklarına ve hemşirelik öğrencilerinin çalıșma sistemine ilişkin görüşleri. TSK Koruyucu Hekimlik Bülteni, 6(6), 459-464

Atay S, Gider D, Karadere G, Şenyüz P. (2009). The views, expectations and problems of nurses' who have been working in hospitals related to in-service education. Journal of Human Sciences, 6(1), 84-93.

Aytekin S, Özer FG, Beydağ K. (2009). Denizli Sağlik Yüksekokulu öğrencilerinin klinik uygulamalarda karşılaştıkları güçlükler. Fırat Sağlık Hizmetleri Dergisi, 4(10), 137-149.

Bayar K, Cadır G, Bayar B. (2009). Determination thought and anxiety levels of nursing students intended for clinical practice. Türk Sİlahlı Kuvvetleri, Koruyucu Hekimlik Bülteni, 8(1), 37-42.

Biçer S, Ceyhan YŞ, Şahin F. (2015). Hemşirelik öğrencileri ve klinik hemşirelerin klinik uygulamada öğrenciye yapılan rehberlik ile ilgili görüşleri. Florence Nightingale Hemşirelik Dergisi, 23(3), 215 223.

Birol, L. (2009). Hemşirelik süreci: hemşirelik bakımında sistematik yaklaşım.(9. Baskı). İzmir: Etki Matbaacılık Yayıncılık, s.59-66.

Cho MH, Kwon IS. (2007). A study on the clinical practice experiences on nursing activities of nursing students. The Journal of Korean academic society of nursing education, 13(2), 143-154.

Elcigil A, Sarı HY. (2007). Determining problems experienced by student nurses in their work with clinical educators in Turkey. Nurse education today, 27(5), 491-498.
Erenel AŞ, Dal Ü, Kutlutürkan S, Vural G. (2008). Hemşirelik dördüncü sınıf öğrencilerinin ve hemşirelerin intörnlük uygulamasına ilişkin görüşleri. Hacettepe Universitesi Sağlık Bilimleri Fakültesi Hemşirelik Dergisi, 16-25.

Erken S. (2008). Klinisyen hemşirelerle akademisyen hemşireler arasındaki iletişim örüntüsünün incelenmesi. DEÜ Sosyal Bilimleri Enstitüsü.

Eskimez Z, Alparslan N, Öztunç G, Torun S. (2005). Hemşirelerin Adana sağlık yüksekokulu öğrencileri ve öğretim elemanlarının klinik uygulamalarına ilişkin görüşleri. Anadolu Hemşirelik ve Sağlık Bilimleri Dergisi, 8(3), 30-39.

Factor EMR, de Guzman AB. (2017). Explicating Filipino student nurses' preferences of clinical instructors' attributes: A conjoint analysis. Nurse education today, 55, 122-127.

Günay U, Kilınç G. (2018). The transfer of theoretical knowledge to clinical practice by nursing students and the difficulties they experience: A qualitative study. Nurse education today, 65, 81-86.

Gürsoy E, Şahin BM, Daanacı B, Arı S. (2017). Hemşirelerin akademik-klinik işbirliğine ilişkin görüşleri: Eskişehir örneği. Dokuz Eylül Üniversitesi Hemşirelik Fakültesi Elektronik Dergisi, 10(3), s.4-6.

Häggman-Laitila A, Elina E, Riitta M, Kirsi S, Leena R. (2007). Nursing students in clinical practicedeveloping a model for clinical supervision. Nurse Education in Practice, 7(6), 381-391.

Hemşirelik Yönetmeliği (2010). Erişim Tarihi: 12.03.2018.

http://www.resmigazete.gov.tr/eskiler/2010/63/2010 0308-4.htm

Henderson A, Cooke M, Creedy DK, Walker R. (2012). Nursing students' perceptions of learning in practice environments: A review. Nurse Education Today, 32(3), 299-302.

Karaöz, S. (2003). Hemşirelikte klinik öğretime genel bir bakış ve etkin klinik öğretim için öneriler. Hemşirelikte Araştırma Geliştirme Dergisi, 1(1), 1521.

Kaya A, Gözüm S, Kaya A, Ünsal A, Unlu F. (2000). Hemşirelik öğrencileri gözüyle klinik hemşireleri. Atatürk Üniversitesi Hemşirelik Yüksekokulu Dergisi, 3(1), 30-31.

Keser IK, Çalışkan M, Keskin T, Gördebil E. (2008). Ebelik ve hemşirelik bölümü öğrencilerinin okulhastane işbirliğine ilişkin görüşlerinin belirlenmesi. Anadolu Hemşirelik ve Sağlık Bilimleri Dergisi, 11(4), 1-9.

Kocaman G. (2004). Türkiye'de hemşirelik eğitim sorunları ve çözüm arayıșları. Hemşirelikte Araştırma Geliștirme Dergisi, 119-150.

Koç M, Batkın D. (2016). Hemşirelik ve ebelik öğrencilerinin uygulama alanlarında meslektaş şiddetine maruz kalma durumları. Anadolu Hemşirelik ve Sağlık Bilimleri Dergisi, 19(3), 189196. 
Konak ŞD, Dericioğulları A, Kılınç G. (2008). Burdur Devlet Hastanesi'nde çalışan hemşirelerin, öğenci hemşirelerinin klinik uygulamalarına ve öğretim elemanlarıyla işbirliği yapmaya ilişkin görüşleri. Medical Journal of Suleyman Demirel University, $15(1), 1-5$.

Rahmani A, Zamanzadeh V, Abdullah-zadeh F, Lotfi M, Bani S, Hassanpour S. (2011). Clinical learning environment in viewpoint of nursing students in Tabriz University of Medical Sciences. Iranian journal of nursing and midwifery research, 16(3), 253. Taylan S, Alan S, Kadıoğlu S. (2012). Hemşirelik rolleri ve özerklik. Turkish Journal of Research \& Development in Nursing, 14(3), 66-73. 